\title{
Participation of rural women in goat rearing in a selected area of Bangladesh
}

\author{
M. Rokonuzzaman and M. S. Islam \\ Chittagong Veterinary and Animal Sciences University, Khulshi, Chittagong-4202, Bangladesh
}

\begin{abstract}
The main purpose of this study was to assess participation of rural women in goat rearing. Pakulla union under Sonatola upazila of Bogra district in Bangladesh was the locale of the study. All the rural goat rearing farm family women heads of Pakulla union constituted the population of the study. Data were collected from a sample of 100 women heads selected randomly during15 December 2008 to 14 January, 2009. The extent of participation of rural women in fifteen items of goat rearing activities was measured through a five-point rating scale. Ten selected characteristics of women were independent variables. Coefficient of correlation ' $r$ ' was computed to test relationship between the dependent and independent variables. Findings revealed that participation of women in goat rearing ranged from 20 to 48 against expected value 0 to 60 with a mean of 35.87 and standard deviation of 8.64. Data also showed that largest portion (63 percent) of the respondents fell into medium participation categories while 28 percent and 9 percent fell into low and high participation categories respectively. Data revealed that participation of rural women in the item 'excreta cleaning of goat' had the highest participation index $(\mathrm{PI}=327)$ and ranked $1^{\text {st }}$, 'looking after the kids' had the second highest participation with PI of 315 and participation in 'caring during pregnancy period' was in $3^{\text {rd }}$ position with $\mathrm{PI}$ of 307 among 15 items. On the other hand the lowest participation was observed in 'arrangement of vaccination' ( $\mathrm{PI}=21$ ) and in 'castration in time' with $\mathrm{PI}$ of 46 among these 15 items.

Correlation analyses indicate that knowledge about goat rearing and extension media contacts were found to have positively significant relationship with participation in goat rearing. On the other hand education, farm size, annual income had negative significant correlation with participation in goat rearing while respondents' age, marital status, family size, credit receipt and grazing land availability had no significant relation with participation in goat rearing. Regarding problem confrontation in goat rearing, data indicated that among the 10 major problems 'lack of proper training about goat rearing' ranked first with 251 problem index (PI). Lack of available grazing land came next in rank (rank 2, PI 242). High mortality rate of kids was the next problem (rank 3, PI 216).
\end{abstract}

Keywords: Participation, Rural women, Goat rearing

\section{Introduction}

Bangladesh is a densely populated country having about 145 millions of people in its $14750 \mathrm{sq}$. $\mathrm{km}$ of area. About 49 percent of population of the country is female (BBS, 2007). Women are most important segment of human resources who need attention for their development. There is a close relationship between the status of women and the socio-economic development in any country. The rate of literacy for women is very low in Bangladesh. It is only 25.5 percent for women compared to 38.9 percent for men. Bangladesh is one of the poorest countries in the world in terms of per capita income which is 482 US dollar (BBS, 2007). To ensure a balanced socio-economic development of the country improvement in the status of women with a change in the status is a precondition. This may be achieved only when there is an increased participation of women in development activities (Naher, 2000 and Alam, 2001). Women play the most dominant part in rearing goat. The role of women in goat keeping is very significant in the rural families and goat is the most important means through which rural women are able to contribute meaningfully to the cash needs for herself and their family members. Goat rearing is the most useful way of womens' earning those who stay at home. However livestock contribute about $2.95 \%$ percent to the GDP (Gross Domestic Product) of Bangladesh and therein total foreign exchange earning accounts for about 6.2 percent (Alam, 1995) in which share of goat is enormous. Goat production varies in different parts of the world. Since production cost of goat is much less than cattle and buffalo goat farming requires small initial investment and as such low risk of loss due to individual death. On the other hand, this species can easily be managed by women and children. Black Bengal goat is developed in this country through natural selection without any intervention by man. Through proper participation of rural women in goat rearing some advantages are given below: to create employment opportunity through goat rearing, to increase income generating activities, to create a new awakening among the neglected section of society, and to preserve and improve 'Black Bengal' variety (Ahmed, 1991).

From the ancient period goat rearing has an important role for the production of meat, milk and skin. Near about 677 million goat in the world, of them 64 percent is found in Asia, 30 percent in Africa, 3.3 percent in North and South America, 2.3 percent in Europe and 0.4 percent in Oceania. In Asia, 71 percent goat reared by small farmer. In case of Bangladesh out of 2 crore goats 52 percent reared by landless marginal farmer (Chowdhury et al., 2002). In Bangladesh the average number of goat per farm is 4, which 
is equal to the South-east Asian countries like Indonesia, Malaysia and Thailand. Forty one percent farm income come from goats in some parts of Bangladesh. Besides leather is the best export goods in Bangladesh that earn 25 crore Taka per year (Chowdhury et al., 2002).

In Bangladesh the men dominated over the women in decision making aspect in rural area. The situation now seems to be changing considerately due to the introduction of new technologies in agriculture like goat rearing, poultry raising, homestead farming etc (Islam et al., 1996). Women and their access to goat rearing is a dimension in the development process. This remained virtually an unexplored area of investigation. After remaining invisible for a long time, it has only recently been surfaced in discussion on development strategies. Now a days the rural women are being approached by different Government and Non Government agencies. On the other hand there is a need to find out working areas for intensifying their participation in agricultural production. In a country like Bangladesh more involvement of women in agriculture particularly goat rearing becomes mandatory to combat over all food storage, malnutrition and also to develop the socio-economic condition of the rural women. Agricultural Extension Service, therefore, needs to develop sound plans and procedure for improving knowledge of the rural women in various aspects of goat rearing. The success of any promotional work depends on the soundness of the extent programs. Information on farmers need, their problems, prospect etc. are essential for an effective plan of work. But very little research has been done on the participation of rural women in goat rearing in Bangladesh. Considering the above facts the investigator became interested to undertake a study on participation of rural women in goat rearing. The following specific objectives have been drawn in order to give proper direction of the study: to examine the selected characteristics of rural women, to assess the extent of participation of rural women in goat rearing, to explore the relationship between selected characteristics of rural women and their extent of participation in goat rearing, and to assess problems faced by the rural women in participating goat rearing

\section{Materials and Methods}

The main purpose of this study was to assess participation of rural women in goat rearing. Pakulla union under Sonatola upazila of Bogra district of Bangladesh was the locale of the study. All the rural goat rearing farm family women heads of Pakulla union constituted the population of the study. Data were collected from a sample of 100 women heads selected randomly during15 December 2008 to 14 January, 2009 through a pre-tested interview schedule. Ten selected characteristics of women were independent variables which are age, education, farm size, annual income, marital status, family size, credit received, knowledge about goat rearing, grazing land availability and extension media contact which was measured through following standard procedure. However their participation in goat rearing was selected as dependent variable in this study and 15 activities which they performed for goat rearing were included to measure this variable. In measuring participation in 15 activities a 5 point rating scale was developed with 5 kind of responses related to participation namely, 'regularly', 'often', 'sometimes', 'rarely' and 'not at all'and the scores assigned for each kind of responses were 4, 3, 2, 1 and 0 , respectively to measure the participation of rural women in goat rearing. Each respondent was asked to indicate her participation in 15 activities following 5 point rating scale. After adding all the responses together on 15 activities, the participation score of a respondent was ascertained. The score could range from 0-60, 0 indicating no participation to 60 indicating very high participation. For better understanding of comparative participation of rural women on 15 activities of goat rearing a Participation Index $(\mathrm{PI})$ was computed using the following formula:

$\mathrm{PI}=\left(\mathrm{P}_{\mathrm{np}} \times 0\right)+\left(\mathrm{P}_{\mathrm{rap}} \times 1\right)+\left(\mathrm{P}_{\mathrm{op}} \times 2\right)+\left(\mathrm{P}_{\mathrm{fp}} \times 3\right)+\left(\mathrm{P}_{\mathrm{rp}} \times 4\right)$

$\mathrm{P}_{\mathrm{np}}=$ Percentage of rural women with no participation

$P_{\text {rap }}=$ Percentage of rural women with rare participation

$\mathrm{P}_{\mathrm{op}}=$ Percentage of rural women with occasional participation

$P_{f p}=$ Percentage of rural women with frequent participation

$\mathrm{P}_{\mathrm{rp}}=$ Percentage of rural women with regular participation

Problem Confrontation Index on participation of goat rearing was prepared by following standard procedure. Statistical Software Package SPSS was used to analyze the collected data. The statistical measures such as range, mean, standard deviation, percentage distribution and rank order were used to describe both the independent and dependent variables. Correlation tests were used to ascertain the relationships between the concerned dependent and the independent variables of the study. 


\section{Results and Discussion}

Data placed in Table 1 reveal that majority (62 percent) fell into middle age category where 21 percent and 17 percent fell into young and old age category respectively. In education level, majority (56 percent) fell into primary categories where 31 percent and 12 percent fell into illiterate and secondary categories respectively. Interestingly only 1 percent fell into higher secondary and above categories (Table 1). Majority (62 percent) fell into small categories of farm size where 20 percent and 18 percent fell into medium and marginal categories of farm size respectively. More than half proportion (55 percent) fell into low category of annual income where 37 percent and 8 percent medium and high categories of annual income respectively. Regarding marital status 72 percent of the respondent fell into married category where only 6 percent fell into unmarried category. Interestingly both widow and divorce categories have comprised same proportion (11 percent). Regarding family size 51 percent fell into medium category where 20 percent and 19 percent fell into small and high categories respectively. About credit receipt more than three fourth (78 percent) fell into not received category where 15 percent and 7 percent fell into low and medium categories of credit receipt. Regarding knowledge about goat rearing majority (68 percent) fell into medium category where 29 percent and only 3 percent fell into low and high categories respectively. In context of grazing land availability majority (57 percent) fell into medium category where 43 percent fell into low category of grazing land availability. Frustratingly there is no respondent fell into high category of grazing land availability (Table 1). Finally regarding extension media contact about half proportion (48 percent) fell into low category where 42 percent and only 2 percent had medium and high contact respectively. Interestingly 8 percent had no contact with extension media (Table 1).

Table 1. Salient feature of selected characteristics of respondents $(N=100)$

\begin{tabular}{|c|c|c|c|c|c|c|c|c|}
\hline \multirow[b]{2}{*}{ SI. No. } & \multirow[b]{2}{*}{ Characteristics } & \multirow[b]{2}{*}{$\begin{array}{l}\text { Measuring } \\
\text { units }\end{array}$} & \multicolumn{2}{|c|}{ Range } & \multirow[b]{2}{*}{ Category } & $\begin{array}{l}\text { Respondents } \\
(\mathrm{N}-100)\end{array}$ & \multirow[b]{2}{*}{ Mean } & \multirow[b]{2}{*}{$\begin{array}{l}\text { Standard } \\
\text { deviation }\end{array}$} \\
\hline & & & 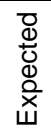 & $\begin{array}{l}\bar{D} \\
\sum_{0} \\
0 \\
0 \\
0\end{array}$ & & $\begin{array}{l}\text { Number \& } \\
\text { Percent }\end{array}$ & & \\
\hline \multirow{3}{*}{1.} & \multirow[t]{3}{*}{ Age } & \multirow{3}{*}{ Year } & \multirow{3}{*}{ 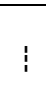 } & \multirow{3}{*}{$\begin{array}{l}L \\
0 \\
0 \\
\infty \\
-1\end{array}$} & Young(upto-30 years) & 21 & \multirow{3}{*}{38.57} & \multirow{3}{*}{5.26} \\
\hline & & & & & Middle (>30-45 years) & 62 & & \\
\hline & & & & & Old $(>45$ years $)$ & 17 & & \\
\hline \multirow{4}{*}{2.} & \multirow{4}{*}{ Education } & \multirow{4}{*}{$\begin{array}{l}\text { Years of } \\
\text { schooling }\end{array}$} & \multirow{4}{*}{ i } & \multirow{4}{*}{ ঙै } & Illiterate $(0)$ & 31 & \multirow{4}{*}{3.82} & \multirow[b]{4}{*}{1.24} \\
\hline & & & & & Primary(1-5) & 56 & & \\
\hline & & & & & Secondary (6-10) & 12 & & \\
\hline & & & & & Higher secondary and above & 01 & & \\
\hline \multirow{3}{*}{3.} & \multirow[t]{3}{*}{ Farm size } & \multirow{3}{*}{ Hectares } & \multirow{3}{*}{ 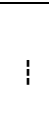 } & \multirow{3}{*}{$\begin{array}{l}0 \\
\text { m. } \\
\stackrel{+}{-} \\
\dot{H} \\
\dot{0} \\
0\end{array}$} & Marginal ( Up to 0.5 ha ) & 18 & \multirow{3}{*}{0.78} & \\
\hline & & & & & Small ( 0.6-1.0 ha) & 62 & & 0.12 \\
\hline & & & & & Medium (> 1.0 ha) & 20 & & \\
\hline & Annual income & & & & Low (upto-50) & 55 & & \\
\hline 4. & & Thousand & 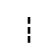 & $\stackrel{m}{\rightarrow}$ & Medium (51-80) & 37 & 48.92 & 7.83 \\
\hline & & & & & High $(>80)$ & 08 & & \\
\hline & & & & & Unmarried & 06 & & \\
\hline 5 & & Number & : & : & Married & 72 & 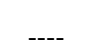 & -1 \\
\hline b. & Marital Status & Number & 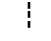 & 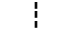 & Widow & 11 & --- & ---- \\
\hline & & & & & Divorce & 11 & & \\
\hline & Family size & & & & Small (up to 4 ) & 20 & & \\
\hline 6. & & Numbers & 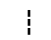 & 각 & Medium ( 5-7) & 61 & 6.18 & 1.65 \\
\hline & & & & & High ( 8- and above) & 19 & & \\
\hline & Credit Receipt & & & & Not received & 78 & & \\
\hline 7. & & Inousand & 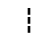 & 7 & Low (1-5) & 15 & 1.05 & 0.12 \\
\hline & & & & & Medium(>5) & 07 & & \\
\hline & Knowledge about & & & & Low (up to 15) & 29 & & \\
\hline 8. & goat rearing & Scores & ri & $\ddot{m}$ & Medium(>15 to 25$)$ & 68 & 16.87 & 4.57 \\
\hline & & & & & High $(>25)$ & 03 & & \\
\hline & Grazing land & & & & Low availability(up to 4) & 43 & & \\
\hline 9. & availability & Scores & $\underset{1}{7}$ & $\stackrel{\infty}{\sim}$ & Medium availability (>4 to 8 ) & 57 & 5.37 & 1.58 \\
\hline & & & & & High availability $(>8)$ & 00 & & \\
\hline & & & & & No contact & 8 & & \\
\hline 10 & Extensions media & & প్ల & $\widetilde{N}$ & Low (up to 15) & 48 & 1383 & 267 \\
\hline 10. & contact & Scores & ó & เ่ & Medium (>15 to 25$)$ & 42 & 13.83 & 2.67 \\
\hline & & & & & High $(>25)$ & 02 & & \\
\hline
\end{tabular}




\section{Participation of Women in Goat Rearing}

Data presented in Table 2 indicate that participation of women in goat rearing ranged from 20 to 48 against expected value 0 to 60 with a mean of 35.87 and standard deviation of 8.64 . However, based on their participation the rural women were classified into three categories as low, medium and high participation categories and their distribution is shown in Table 2.

Data presented in the Table 2 show that largest portion (63 percent) of the respondents fell into medium participation category while 28 percent and 9 percent fell into low and high participation categories respectively. An overwhelming majority of the women fell into low to medium participation category.

\section{Table 2. Participation of Women in Goat Rearing}

\begin{tabular}{|c|c|c|c|c|c|c|c|}
\hline \multirow[b]{2}{*}{ Characteristics } & \multirow[b]{2}{*}{$\begin{array}{l}\text { Measuring } \\
\text { units }\end{array}$} & \multicolumn{2}{|c|}{ Range } & \multirow[b]{2}{*}{ Category } & \multirow{2}{*}{$\begin{array}{c}\begin{array}{c}\text { Respondents } \\
(\mathrm{N}-100)\end{array} \\
\text { Number \& } \\
\text { Percent }\end{array}$} & \multirow[b]{2}{*}{ Mean } & \multirow[b]{2}{*}{$\begin{array}{l}\text { Standard } \\
\text { deviation }\end{array}$} \\
\hline & & 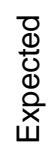 & $\begin{array}{l}\bar{D} \\
\mathbb{D} \\
2 \\
0 \\
0 \\
0\end{array}$ & & & & \\
\hline \multirow{3}{*}{$\begin{array}{l}\text { Participation of } \\
\text { Women in Goat } \\
\text { rearing }\end{array}$} & \multirow{3}{*}{ Score } & \multirow{3}{*}{$\begin{array}{l}\text { @ } \\
\vdots\end{array}$} & \multirow{3}{*}{ 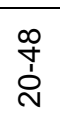 } & Low Participation (up to-30) & 28 & \multirow{3}{*}{35.87} & \multirow{3}{*}{8.64} \\
\hline & & & & Medium Participation (>30 to 40 ) & 63 & & \\
\hline & & & & High Participation (>40) & 09 & & \\
\hline
\end{tabular}

\section{Aspects of rural women's participation in goat rearing}

Extent of participation of rural women in each of the fifteen selected items related to goat rearing has been shown in table 3 along with participation indexes and rank order. Computed participation indexes against 15 items ranged from 21 to 327 .

Data furnished in table 3 reveal that participation of rural women in the item 'excreta cleaning of goat' had the highest participation index $(\mathrm{PI}=327)$ and ranked $1^{\text {st }}$, 'looking after the kids' had the second highest participation with $\mathrm{PI}$ of 315 and participation in 'caring during pregnancy period' was in $3^{\text {rd }}$ position with PI of 307 among 15 items. All of these items are very much associated with women and naturally they perform these operations and thus participation was high (Table 3). The lowest participation was observed in 'arrangement of vaccination' ( $\mathrm{Pl}=21$ ) and in 'castration in time' with $\mathrm{PI}$ of 46 (Table 3). Alam et al. 2001 also observed similar results.

Table 3. Comparative participation of rural women in 15 items of goat rearing with participation Indices (PI) and rank order

\begin{tabular}{|c|c|c|c|c|c|c|c|}
\hline \multirow[t]{2}{*}{ Items in goat rearing } & \multicolumn{5}{|c|}{ Percent of women } & \multirow{2}{*}{$\begin{array}{l}\text { Participation } \\
\text { Index (PI) }\end{array}$} & \multirow{2}{*}{$\begin{array}{l}\text { Rank } \\
\text { Order }\end{array}$} \\
\hline & $\begin{array}{c}\text { Regular } \\
\text { (4) }\end{array}$ & Often (3) & $\begin{array}{c}\text { Some time } \\
\text { (2) }\end{array}$ & Rarely (1) & Never (0) & & \\
\hline Excreta cleaning of goat & 65 & 7 & 22 & 2 & 4 & 327 & 1 \\
\hline Looking after the kids & 57 & 9 & 29 & 2 & 3 & 315 & 2 \\
\hline Caring during pregnancy period & 52 & 12 & 30 & 3 & 3 & 307 & 3 \\
\hline Collection of goat from field during evening & 45 & 15 & 26 & 10 & 4 & 287 & 4 \\
\hline Nursing during labour & 43 & 17 & 23 & 11 & 6 & 280 & 5 \\
\hline Collection of leaves as feed & 38 & 21 & 21 & 15 & 5 & 272 & 6 \\
\hline Bathing of goat in proper time & 34 & 25 & 20 & 17 & 4 & 268 & 7 \\
\hline Collection of milk & 25 & 14 & 22 & 21 & 18 & 207 & 8 \\
\hline Grazing in the field & 20 & 15 & 23 & 18 & 24 & 189 & 9 \\
\hline Clothing during winter & 17 & 13 & 27 & 23 & 20 & 184 & 10 \\
\hline Collection of goat & 10 & 11 & 22 & 25 & 32 & 142 & 11 \\
\hline Mating in time & 7 & 9 & 23 & 27 & 34 & 128 & 12 \\
\hline Selling & 5 & 7 & 18 & 33 & 37 & 110 & 13 \\
\hline Castration in time & 1 & 0 & 17 & 8 & 74 & 46 & 14 \\
\hline Arrangement of vaccination & 1 & 1 & 2 & 10 & 86 & 21 & 15 \\
\hline
\end{tabular}


Relationship Between the characteristics of Rural Women and their Participation in Goat rearing

Correlation analyses indicate that knowledge about goat rearing and extension media contacts were found to have positively significant relationship with participation in goat rearing (Table 4). On the other hand, education, farm size, annual income had negative significant relationship with participation in goat rearing while respondents' age, marital status, family size, credit receipt and grazing land availability had no significant relation with participation in goat rearing (Table 4).

Table 4. Co-efficient of correlation ( $r$ ) between independent and dependent variable of the study

\begin{tabular}{|c|c|c|c|c|}
\hline \multirow[t]{2}{*}{ Dependent variable } & \multirow[t]{2}{*}{ Independent variables } & \multirow[t]{2}{*}{ Computed value of ' $r$ ' } & \multicolumn{2}{|c|}{$\begin{array}{c}\text { Table value 'r' with } 98 \text { degrees } \\
\text { of freedom }\end{array}$} \\
\hline & & & 0.05 level & 0.01 level \\
\hline \multirow{10}{*}{$\begin{array}{l}\text { Participation in goat } \\
\text { rearing }\end{array}$} & Age & $0.181^{\mathrm{NS}}$ & \multirow{10}{*}{ \pm 0.196} & \multirow{10}{*}{ \pm 0.257} \\
\hline & Education & $-0.275^{\star \star}$ & & \\
\hline & Farm size & $-0.298^{\star \star}$ & & \\
\hline & Annual Income & $-0.307^{\star \star}$ & & \\
\hline & Marital status & $0.136^{\mathrm{NS}}$ & & \\
\hline & Family size & $-0.147^{\mathrm{NS}}$ & & \\
\hline & Credit receipt & $0.154^{\mathrm{NS}}$ & & \\
\hline & Knowledge about goat rearing & $0.207^{*}$ & & \\
\hline & Grazing land availability & $-0.138^{\mathrm{NS}}$ & & \\
\hline & Extension Media contact & $0.214^{*}$ & & \\
\hline
\end{tabular}

${ }^{* *}=$ Significant at 0.01 level of probability, ${ }^{*}=$ significant at 0.05 level of probability and NS $=$ Not significant

\section{Problem faced by the Rural Women in Participating Goat Rearing Activities}

Generally we face a number of problems or constraints in performing any production activity. In case of livestock activities the extent and types of problems are diversified. However, rural women of the study area mentioned 10 problems which are given in table 5 with rank in descending order of importance.

Data in table 5 indicated that among the 10 major problems 'lack of proper training about goat rearing' ranked first with 251 problem index $(\mathrm{PI})$. Lack of available grazing land came next in rank (Rank 2, PI 242). High mortality rate of kids was the next problem (rank 3, PI 216). Problem regarding goat shed came next in order (rank 4, PI 214). Apart from these 'lack of adequate capital', 'lack of good breed of goat', 'high price of veterinary medicine', 'lack of necessary vaccine for controlling disease of goat', 'intrusion to others land by goat' and 'lack of knowledge about artificial insemination for improvement of goat' with problem index 207, 195, 164, 156,132 and 120 ranked $5^{\text {th }}, 6^{\text {th }}, 7^{\text {th }}, 8^{\text {th }}, 9^{\text {th }}$ and $10^{\text {th }}$ respectively.

Table 5. Rank order of the problem faced by the rural women

\begin{tabular}{|l|c|c|c|c|c|}
\hline \multicolumn{1}{|c|}{ Problems } & \multicolumn{2}{c|}{$\begin{array}{c}\text { Number of respondent against } \\
\text { each of the three problem level }\end{array}$} & $\begin{array}{c}\text { Problem } \\
\text { Index (PI) }\end{array}$ & $\begin{array}{c}\text { Rank } \\
\text { Order }\end{array}$ \\
\cline { 2 - 4 } & High (3) & Moderate (2) & Low (1) & \\
\hline Lack of proper training about goat rearing & 70 & 11 & 19 & 251 & $\mathbf{1}$ \\
\hline Lack of available grazing land & 60 & 22 & 18 & 242 & $\mathbf{2}$ \\
\hline High mortality rate of kids & 53 & 20 & 17 & 216 & $\mathbf{3}$ \\
\hline Problem regarding goat shed & 32 & 50 & 18 & 214 & $\mathbf{4}$ \\
\hline Lack of adequate capital & 30 & 47 & 23 & 207 & $\mathbf{5}$ \\
\hline Lack of good breed of goat & 25 & 45 & 30 & 195 & $\mathbf{6}$ \\
\hline High price of veterinary medicine & 20 & 24 & 56 & 164 & $\mathbf{7}$ \\
\hline Lack of necessary vaccine for controlling disease of goat & 16 & 24 & 60 & 156 & $\mathbf{8}$ \\
\hline Intrusion to others land by goat & 10 & 12 & 78 & 132 & $\mathbf{9}$ \\
\hline $\begin{array}{l}\text { Lack of knowledge about artificial insemination for } \\
\text { improvement of goat }\end{array}$ & 5 & 10 & 85 & 120 & $\mathbf{1 0}$ \\
\hline
\end{tabular}




\section{Conclusion}

In the present study overall participation of rural women in goat rearing was low to medium. In fact women in our country belong to conservative society who face different sorts of social obstacle to rear goat which rightly been reflected in this study. So, there is a need for strengthening extension work by GOs and NGOs to ensure a continuous flow of information to overcome these sorts of social obstacle in goat rearing. However, rural women of the study area mentioned 10 problems. These problems created disturbances in implementing the goat rearing activities. Therefore, it may be concluded that goat rearing activities of the rural women will be continuously disturbed if the above problems are not handled in an appropriate way. Most of the rural women were young to middle aged while age of the rural women had no significant relationship with their participation in goat rearing. But, as larger proportion of the rural women is middle aged, so it may be necessary to give some importance to these categories.

\section{References}

Ahmed, N. 1991. Problems and Prospect of Livestock in Bangladesh. A paper presented in the annual Meeting-cum-workshop on Livestock Research Institute, Savar.

Anonymous. 2007. Bangladesh Economic Review, Economic Adviser's Wing, Finance Division, Ministry of Finance, Government of the People's Republic of Bangladesh.

Alam, J. 1995. Livestock Resources in Bangladesh: Present Status and Future Potential. Dhaka: University Press Limited.

Alam, J., Sayeed, M.A. And Ray, S.K. 2001. Women's Participation in Raising Livestock in Some Selected Areas of Bangladesh. Bangladesh Livestock Research Institute.(BLRI), Savar, Dhaka.pp.12-21.

Alam, M.S. 2001. Performance of Thengamara Mohila Subuj Shangha Beneficiaries of Three Unions Under Sadar Upazilla of Bogra District. M.S.(Ag.Ext.Ed.)Thesis. Department of Agricultural Extention Education, Bangladesh Agricultural University, Mymensingh.

BBS. 2007. Statistical Yearbook of Bangladesh, Bangladesh Bureau of Statistics. Ministry of Planning,Government of the Peoples Republic of Bangladesh, Dhaka, Bangladesh.

Chowdhury, S.A., Sil, B.K.and Hossain, S.M.J. 2002. Goat Production Mannual. Bangladesh Livestock Research Institute.(BLRI), Savar, Dhaka. 1341. And Department of Livestock Services, Krishi Khamar Sarak, Farmgate, Dhaka-1215.

Islam, M.S., Bhuiyan, A.K.M.A.H. and Karim, A.M.A. 1996. Women Participation in Agricultural Income Generating Activities. Journal of the Asiatic society of Bangladesh Science,22 (2).

Naher, K. 2000. Participation of Rural Women in Homestead Agriculture in a Selected Area of Gazipur District. M.S. (Ag. Ext, Ed.)Thesis. Department of Agricultural Extension Education. Bangladesh Agricultural University, Mymensingh. 